Perilaku Etika Bisnis Pedagang Sayur Di Pasar Tradisional....

\title{
PERILAKU ETIKA BISNIS PEDAGANG SAYUR DI PASAR TRADISIONAL MANGGISAN TANGGUL PERSPEKTIF ABU HAMID MUHAMMAD AL-GHAZALI
}

\author{
Diny Duratul Ummah \\ Mahasiswa Pascasarjana UIN KHAS Jember \\ dinyummah@gmail.com
}

\author{
Ainul Churria Almalachim \\ Dosen STISMU Lumajang \\ ielmhaamigos@gmail.com
}

\begin{abstract}
The Manggisan ebankment market is a traditional market where the people conduct daily buying and selling transactions. In conducting business activities does not deny the existence of frand that can be caused by a lack of awareness and knowledge in doing business based on Islamic business ethics. Awareness of the application of business ethics values must be carried out by every market player. Syari'ah business ethics is a moral reference as part of Islamic forms of Akblaqul Karimah in muamalah. Islamic business ethics is based on monotheism, honesty, justice (balance) and kindness (ihsan). In conducting business activities Abu Hamid Mubammad Al Ghazali emphasied to always be guided by Islamic business ethics because by doing so a Muslim in doing his business will get two advantages namely the world and the hereafter. The formulation of the problem from this study is how the behavior of the vegetable traders ethics in the embankment Manggisan market. And how the behavior of greengrocer business ethics in the market of Abu Hamid Mubammad Al Ghazali's embankment perspective. This research is a type of (field research) by using juridical empirical methods, namely methods that collect data by means af observation, interviews and documentation of the behavior of business ethics of vegetable traders in conducting business activities.Based on the result of the study, it can be concluded that in general the vegetable traders in the Manggisan embankment market have applied business ethics behavior in their business activities. Including starting a business by reading basmalah, not reducing scales and not taking very much profit, even though in reality they do not understand that what they are doing is part of the theory of business ethics. But there are still traders who someties are rude to buyers due to having personal problems with their families, this is considered to have violated Islamic business ethis. One of the principles that must be possessed by a Muslim trader is to be good so that what is done will provide
\end{abstract}

206 | FENOMENA, Vol.18 No. 2Oktober 2019 
benefits to others so that the business carried out does not only benefit themselves but also benefits others.

Keywords: Ethics, Business, Traders, Abu Hamid Muhammad Al Ghazali.

\begin{abstract}
ABSTRAK
Pasar Manggisan Tanggul merupakan pasar tradisional tempat dimana para masyarakatnya melakukan transaksi jual beli kebutuhan sehari-hari. Dalam melakukan aktivitas bisnis tidak menafikan adanya kecurangan yang bisa disebabkan kurangnya kesadaran dan pengetahuan dalam melakukan bisnis dengan berlandaskan etika bisnis Islam. Kesadaran penerapan nilai-nilai etika bisnis harus dilakukan oleh setiap pelaku pasar. Etika bisnis Syariah merupakan acuan moral sebagai bagian dari wujud Akblakul Karimah dalam muamalah yang berbasis Islami. Etika bisnis Islam didasarkan pada sikap tauhid, jujur, keadilan (keseimbangan), dan kebaikan (ihsan). Dalam melakukan aktivitas bisnis Abu Hamid Muhammad Al-Ghazali menekankan untuk selalu berpedoman pada etika bisnis Islam karena dengan begitu seorang muslim dalam melakukan bisnisnya akan memperoleh dua keuntungan yaitu dunia dan akhirat. Rumusan masalah dari penelitian ini adalah bagaimana perilaku etika bisnis pedagang sayur di pasar tradisional Manggisan Tanggul, dan bagaimana perilaku etika bisnis pedagang sayur di pasar tradisional Manggisan Tanggul perspektif Abu Hamid Muhammad Al-Ghazali. Penelitian ini merupakan jenis penelitian lapangan (Field Research) dengan menggunakan metode yuridis empiris yaitu metode yang pengumpulan datanya dengan cara observasi, wawancara, dan dokumentasi mengenai perilaku etika bisnis pedagang sayur dalam melakukan kegiatan bisnisnya. Berdasarkan hasil penelitian dapat disimpulkan secara umum para pedagang sayur di Pasar Manggisan Tanggul telah menerapkan perilaku etika bisnis dalam kegiatan bisnisnya diantaranya memulai usahanya dengan bacaan basmalah, tidak mengurangi timbangan serta tidak mengambil keuntungan sangat banyak meskipun pada kenyataannya mereka tidak mengerti bahwa yang mereka lakukan adalah bagian dari teori etika bisnis. Namun masih ada pedagang yang terkadang bersikap kasar kepada pembeli akibat memiliki masalah pribadi dengan keluarganya, hal tersebut dianggap telah menyalahi etika bisnis Islam. Salah satu prinsip yang harus dimiliki seorang pedagang muslim adalah bersikap baik agar setiap yang dikerjakan memberikan kemanfaatan kepada orang lain sehingga bisnis yang dilakukan tidak hanya memberikan keuntungan bagi diri sendiri akan tetapi juga kepentingan orang lain.
\end{abstract}

Kata Kunci: Etika, Bisnis, Pedagang, Abu Hamid Mubammad Al-Ghazali.

FENOMENA, Vol.18 No. 2Oktober 2019 | 207 


\section{PENDAHULUAN}

Perilaku adalah pandangan-pandangan atau perasaan yang disertai kecenderungan untuk bertindak sesuai sikap objek. Perilaku juga dapat disebut sebagai tingkah laku seseorang senantiasa didasarkan pada kondisi, yaitu tindakan mengenal atau memikirkan seseorang terlibat langsung dalam situasi memecahkan masalah. ${ }^{1}$

Salah satu yang mempengaruhi perilaku manusia adalah pendekatan perilaku yang berhubungan dengan psikologi manusia. Behaviorisme (pendekatan perilaku) adalah pendekatan yang sangat bermanfaat untuk menjelaskan persepsi interpersonal, konsep diri, eksperimen, sosialisasi serta ganjaran dan hukum. Behaviorisme percaya bahwa perilaku manusia adalah hasil dari proses belajar. Manusia belajar dari hasil lingkungannya dan hasil itulah yang berperilaku. Oleh karena itu, manusia dapat dipengaruhi oleh lingkungannya. ${ }^{2}$

Dapat disimpulkan bahwa perilaku adalah segala tindakan manusia meliputi cara berbicara, melakukan sesuatu, dan bereaksi terhadap segala sesuatu yang terjadi pada dirinya yang datang dari dirinya ataupun orang lain, yang tertunya didasari maupun tidak didasari oleh apapun. Perilaku disini sesuai dengan kondisi yang dialaminya. Jadi tindakan yang dilakukan tidak membutuhkan fikiran dalam artian spontan begitu saja.

Pasar selama ini sudah menyatu dan memiliki tempat paling penting dalam kehidupan masyarakat sehari-hari, bagi masyarakat pasar bukan hanya tempat bertemunya antara penjual dan pembeli tetapi juga sebagai wadah untuk berinteraksi sosial. Para ahli ekonomi mendeskripsikan sebuah pasar sebagai sekumpulan penjual dan pembeli yang melakukan transaksi atas suatu produk tertentu atau kelompok produk tertentu. ${ }^{3}$

Sesuai dengan perkembangannya pasar dikenal dengan pasar tradisional maupun pasar modern. Pasar tradisional biasanya menampung banyak penjual, dilaksanakan dengan manajemen tanpa perangkat teknologi modern dan mereka lebih memiliki golongan pedagang menengah kebawah dan ter-

\footnotetext{
${ }^{1}$ Dyan Arrum Rahmadani, Perilaku pedagang di Pasar Tradisional Petepapus Makassar dalam Perspektif Etika Bisnis Islam, Skripsi (Makassar: Fakultas Ekonomi dan Bisnis Islam UIN Alauddin Makassar, 2017), h. 12.

2Dyan Arrum Rahmadani, Perilaku pedagang, h. 13.

${ }^{3}$ Siti Mina Kusnia, Perilaku Pedagang di Pasar Tradisional Ngaliyan Semarang dalam Perspektif Etika Bisnis Islam, Skripsi (Semarang : UIN Walisongo 2015), h.1
}

208 | FENOMENA, Vol.18 No. 2Oktober 2019 
sebar, baik di kampung-kampung kota-kota kecil dan kota-kota besar dengan masa operasi rata-rata dari subuh sampai siang atau sore hari. Sedangkan pasar modern adalah pasar yang menggunakan teknologi modern, konsumennya dan pedagang dari golongan menengah ke atas, harga yang ditawarkan tetap dan sistem pelayanannya sendiri. ${ }^{4}$

Dalam ekonomi Islam visi misi bisnis tidak hanya berorientasi pada maksimalisasi laba seperti halnya pada kaum kapitalis yang berprinsip pada biaya rendah dapat menghasilkan keuntungan yang besar, melainan visi misi bisnis Islami lebih mengedepankan manfaat dari suatu produk serta keberkahan dalam memperoleh keuntungan. ${ }^{5}$

Suatu pernyataan yang kita hadapi di masyarakat perilaku yang menyimpang dari ajaran agama, merosotnya etika dalam bisnis, tumbuh gejala-gejala kurangnya rasa solidaritasan, tanggung jawab sosial dan tingkat kejujuran, saling curiga, sulit percaya pada seorang pengusaha jika berhubungan untuk pertama kali. Namun ada saja yang mencari peluang untuk menipu setelah terjadi hubungan dagang mulus dan lancar beberapa kali. Dimana pembayaran lancar sudah saling percaya satu sam lain. Tapi akhirnya yang satu menipu yang lainnya memanfaatkan kepercayaan yang baru terbentuk ini.

Pasar Manggisan Tanggul adalah salah satu pasar tradisional yang beroperasi di kecamatan Tanggul yang didirikan kurang lebih pada tahun 1991 sampai sekarang. Pasar Manggisan Tanggul menjadi fokus penelitian ini karena para pedagangnya mayoritas seorang muslim tentunya tidak menafikan adanya pelaksanaan etika bisnis islam. Namun juga tidak dapat dipungkiri dengan berbagai watak dari pelaku bisnis baik antara penjual dan pembeli dapat memicu adanya peselisihan dan ketidaksesuaian dalam melakukan kesepakatan. Terkadang terjadi pertengkaran akibat masing-masing pihak mempertahankan kemauannya yang nyatanya bertolak belakang dengan ketetuan etika bisnis syariah.

Syari'at Islam telah mengajarkan segala tata cara manusia dalam menjalankan kehidupan dari segala aspek. Bukan hanya dalam aspek religius, akan tetapi juga mengatur bagaimana manusia sebagai makhluk sosial, men-

\footnotetext{
${ }^{4}$ Ibid. h.1

${ }^{5}$ Ligaya Safitri, Etika Bisnis Mahasiswa (Studi Kasus pada Mahasiswa Prodi Ekonomi Islam Angkatan 2011 Fakultas Ekonomi dan Bisnis Islam UIN Wali Songo Semarang), skripsi (Semarang :UIN Wali Songo, 2015), h. 3
}

FENOMENA, Vol.18 No. 2Oktober 2019 | 209 
jaga hubungan antar sesama manusia, hubungan manusia dan alam, serta menghindari perilaku yang menyimpang agar tercipta kedamaian, ketentraman, dan kesejahteraan. Tidak hanya itu, Islam sebagai agama universal telah mengatur hal yang berkaitan dengan aspek ekonomi manusia, sehingga ekonomi yang dijalankan tidak hanya berorientasi pada kebahagiaan dunia akan tetapi kebahagiaan akhirat kelak.

Dalam kehidupan sehari-hari kita sering mendengar istilah akhlak, moral, etika. Ketiganya sangat akrab ditelinga kita sehingga tidak terpikirkan apakah istilah tersebut memiliki perbedaan atau sebaliknya. Jika dilihat dari tolok ukur masing-masing perbedaan itu pasti ada. Kata "akblaq" yang berasal dari bahas arab, yang diartikan dengan budi pekerti, perangai, tingkah laku atau tabiat. Kemudian diadopsi menjadi bahasa Indonesia yaitu "akhlak" tolok ukurnya adalah Al-Quran dan Hadis. ${ }^{6}$ Namun dalam AlQur'an yang ditemukan adalah bentuk tunggal kata tersebut, yaitu khuluq yang tercantum dalam Al-Qur'an surat al-Qalam (68) ayat 4:

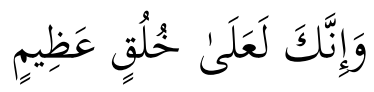

Artinya: Dan Sesunggubnya engkau benar-benar, berbudi pekerti yang agung. ${ }^{7}$

Dalam memenuhi kebutuhan hidup, syari'at Islam mengajarkan saling tolong-menolong dari kebaikan agar terhindar dari kemungkaran. penerapan dari bisnis yang berbasis syari'ah tidak hanya fokus pada kepentingan materil akan tetapi juga memperhatikan aspek non-materil, yaitu kesabaran, kesyukuran, keperdulian. Bisnis syari'ah juga akan menjauhkan pebisnis dari perbuatan tecela seperti kikir, tamak, manipulasi, penipuan, yang tentunya akan merugikan diri sendiri dan lingkungannya. Oleh sebab itu seorang muslim yang baik harus mengutamakan etika bisnis ketika melakukan aktivitas ekonominya agar diantara kedua belah pihak sama-sama mendapat keuntungan dan tidak merasa dirugikan satu sama lain.

Aktivitas bisnis sangat diperlukan, karena setiap orang tidak mampu mencukupi kebutuhannya sendiri tanpa bantuan orang lain. Karena dalam pemenuhan kebutuhan tersebut kita perlu berinteraksi dengan orang lain maka Al-Qur'an sebagai pedoman hidup umat Islam telah menjelaskan

${ }^{6}$ Muhammad Djakfar, Etika Bisnis, (Cet. 1;Jakarta: Penebar Plus imprint, 2012), h. 12.

${ }^{7}$ Departemen Agama RI, Al-Qur'an dan terjemahnya ( Tangerang: Kalim), h. 565.

210 | FENOMENA, Vol.18 No. 2Oktober 2019 
bagaimana kita seharusnya bersikap dalam melakukan aktivitas mu'amalah agar sesuai dengan yang telah difirmankan oleh Allah SWT. Sudah sepatutnya seorang hamba yang taat mengikuti penjelasan yang telah tertera dalam Al-Qur'an agar bisnis yang dijalankan berhasil dunia dan akhirat. Dalam hal ini Allah menjelaskan dalam surat Al-Maidah ayat 2 sebagai berikut:

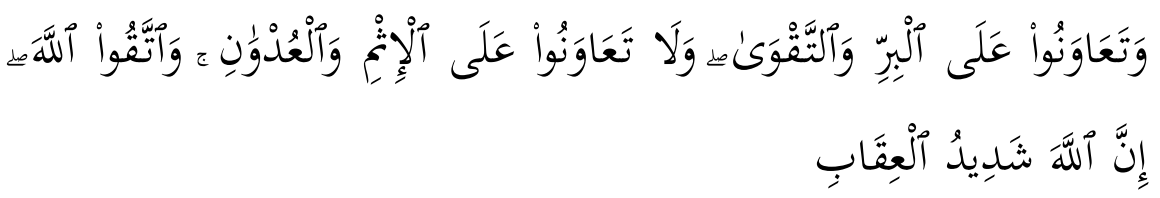

Artinya: "Dan tolong-menolonglah kamu dalam (mengerjakan) kebajikan dan takwa, dan jangan tolong-menolong dalam berbuat dosa dan pelanggaran. Dan bertakwalah kamu kepada Allah. Sesunggubnya Allah amat berat siksaNya". 8

Seiring dengan perkembangan zaman, yang ditandai dengan perkembangan ekonomi yang sangat pesat menimbulkan persaingan bisnis semakin tinggi. Dengan persaingan yang begitu tinggi para pelaku bisnis menggunakan segala cara untuk mendapat keuntungan bahkan para pelaku bisnis sering mengabaikan etika dalam menjalankan bisnis. Seperti contoh banyak ditemukan para pedagang yang mengabaikan etika dalam menjalankan bisnisnya. Masih banyak para pedagang yang melakukan penyimpanganpenyimpangan dalam berdagang. Masalah yang rawan terjadinya penyimpangan adalah pasar tradisional. Perilaku menyimpang ditemukan di pasar tradisional antara lain pengurangan takaran dari timbangan, pengoplosan barang kualitas bagus dengan yang buruk, dan penjualan barang haram. ${ }^{9}$

Kejujuran dalam memberikan informasi sangat diperlukan oleh pembeli apalagi kejujuran merupakan penentuan usaha agar berjalan dalam jangka waktu yang lama dengan memiliki keprcayaan dari para pembeli. Oleh karena dunia bisnis penuh persaingan, maka aturan dalam bisnis tidak sama dengan aturan kehidupan sosial, orang yang mempertahankan etika dalam berbisnis akan tersingkir jauh dari orang-orang yang menghalalkan segala

\footnotetext{
${ }^{8}$ Departemen Agama RI, Al-Qur'an dan terjemahnya ( Tangerang: Kalim), h. 106

${ }^{9}$ Ema Mardiyah, Asep Suryanto, Analisis Penerapan Etika BisnisSyari'ah di Pasar Tradisional

Singaparna Kab. Tasikmalaya, Skrpsi (Fakultas Ekonomi Universitas Tasikmalaya, 2010), h. 2.
}

FENOMENA, Vol.18 No. 2Oktober 2019 | 211 
macam cara untuk mendapat keuntungan. Karena mereka menganggap bisnis tidaklah memiliki tanggung jawab sosial, dan bisnis terlepas dari etika. Padahal pada hakikatnya harta adalah milik Allah SWT dan manusia hanya dititipkan amanah untuk mengelolanya.

Definisi-definisi diatas memperlihatkan bahwa akhlak adalah suatu keadaan yang tertanam dalam jiwa berupa keinginan kuat yang melahirkan perbuatan-perbuatan secara langsung dan berulang-ulang tanpa memerlukan pemikiran secara lanjut. Keadaan jiwa itu adakalanya merupakan sifat alami yang didorong oleh fitrah manusia untuk melakukan suatu tindakan atau tidak melakukannya. Perbuatan yang lahir itu merupakan tanda dan bukti adanya akhlak tersebut. ${ }^{1}$

0

Diera reformasi ini, Al-Ghazali merupakan salah satu seorang yang menyinggung masalah etika terutama dalam hal berniaga. Begitu banyak buah karya beliau sedikit banyaknya memebahas tentang etika bisnis, misalnya saja kitab fenomenal beliau yaitu Ihya'ulumuddin yang secara komprehensif membahas seputar etika bisnis. Pemikiran Al-Ghazali telah diakui oleh banyak pihak karena tidak hanya berlaku pada zamannya, namun juga berlaku pada konteks tertentu dan dapat menjawab berbagai persoalan kemanusiaan kontemporer. ${ }^{1}$

Dalam dunia bisnis, begitu banyak teori yang beliau kemukakan, misalnya saja tentang teori fungsi uang, pasar, pajak, dan lain sebagainya yang tidak melepaskan unsur etika didalamnya. Beliau senantiasa membahas itu semua berdampingan dengan prinsip etika yang diwarnai dengan pemikiran tasawufnya. Peran etika dalam dunia bisnis sangat penting, karena setiap orang yang berinteraksi diranah ekonomi diharuskan menjaga amanah, tanggung jawab serta tidak berbuat aniaya terhadap orang lain.

Al-Ghazali dikenal memiliki pemikiran yang luas dalam berbagai bidang. Bahasannya tentang ekonomi dapat ditemukan dalam karya monumentalnya Ihya' Ulum al Din, disamping dalam Usul al Fiqh, al Mustafa, Mizan al Amal dan Thabir al Masbuk. fi Nasihat al Muluk. ${ }^{1}$

${ }^{1}$ Fahadil Amin Al-Hasan, Etika Bisnis Al-Ghazali. Jurnal El-Sya. 2014. Vol. 1 No. 1. Hal 5-6.

1 Fahadil Amin, Etika Bisnis A1-Ghazali. Jurnal El-Sya. 2014. Vol. 1 No. 1. Hal 1.

${ }^{1}$ Nur Chamid, Jejak Langkah² sejarah Pemikiran Ekonomi Islam, (Cet. 1; Yogyakarta: Pustaka Pelajar, 2010), h. 220.

212 | FENOMENA, Vol.18 No. 2Oktober 2019 
Secara mengejutkan, Al-Ghazali menyuguhkan pembahasan terperinci tentang peranan dan signifikasi aktivitas perdagangan yang dilakukan dengan sukarela, serta proses timbulnya pasar yang berdasarkan kekuatan permintaan dan penawaran untuk menentukan harga dan laba. Bagi AlGhazali pasar berevolusi sebagai bagian dari "Hukum Alam" segala sesuatu, yakni sebuah ekspresi sebagai hasrat yang timbul dari diri sendiri untuk saling memuaskan kebutuhan ekonomi. ${ }^{1}$

3

\section{METODE PENELITIAN}

Penelitian ini merupakan penelitian lapangan (yuridis empiris) yang mana pada penelitian ini pendekatan yang digunakan adalah pendekatan kasus (Case Aprroach) pendekatan ini dilakukan dengan melakukan telaah pada kasus yang berkaitan dengan isu hukum yang dihadapi. Sumber data yang digunakan adalah sumber data primer yang diperoleh langsung dari lapangan dengan beberapa cara yaitu wawancara, observasi dan laporan dalam bentuk dokumen tidak resmi dan sebagai data tambahan mengunakan sumber data sekunder yaitu data yang diperoleh dari dokumen resmi, buku-buku, hasil penelitian dalam bentuk laporan, skripsi, thesis, disertasi, peraturan perundang undangan, dan terjemah kitab Ibya' Ulumuddin Teknik pengumpulan data dilakukan adalah observasi, wawancara dan dokumentasi. Dalam menganalisa data menggunakan metode Miles and Huberman yang dilakukan pada saat pengumpulan data berlangsung dengan tiga alur kegiatan yang terjadi secara bersamaan yaitu reduksi data, penyajian data, dan penarikan kesimpulan/ verifikasi. Terakhir untuk menguji keabsahan data menggunakan perpanjangan pengamatan dan tringulasi.

\section{PERILAKU PEDAGANG SAYUR DI PASAR MANGGISAN DA- LAM PERSPEKTIF AL-GHAZALI}

Perilaku pedagang merupakan sikap atau tindakan seseorang ketika melakukan perdagangan. Dalam penelitian ini peneliti mengambil 5 responden pedagang sayur di pasar Tradisional Manggisan Tanggul. Dari hasil penelitian yang dilakukan ada beberapa perilaku yang sering dilakukan oleh pedagang, yang pertama dalam hal takaran dan atau timbangan. Dalam menimbang suatu barang dagangan para pedagang memiliki sikap yang berbeda-

\footnotetext{
${ }^{1}$ Misdi Rianto, Pemikiran Al³Ghazali tentang Mekanisme Pasar dalam Islam, Skripsi (Riau: UIN Sultan Syarif Kasim, 2010), h. 6.
}

FENOMENA, Vol.18 No. 2Oktober 2019 | 213 
beda, seperti dari hasil wawancara pada lima responden pedagang sayur di Pasar Manggisan Tanggul berikut ini.

1. Prinsip Ketuhanan (unity)

Berdasarkan hasil wawancara mengenai kebarokahan, pekerjaan adalah suatu ibadah dimana berarti usaha yang dilakukan berorientasi pada kehidupan akhirat. Ketiga responden Ibu Iyon, Bapak Abdullah, Ibu Hedar dari pernyataan yang diungkapkan ketiga reponden adalah dimana mereka selalu menyertai usaha yang dilakukannya dengan ucapan basmalah dan sholawat yang mengirinya menandakan bahwa ketentuan rezeki adalah mutlak milik Allah, kita sebagai manusia diperintahkan untuk berdo'a dan usaha agar apa yang kita kerjakan disamping memberikan keuntungan duniawi juga bernilai pahala diakhirat. Karena tujuan kita adalah meraih kebahagiaan akhirat dengan menjadikan dunia sebagai alat pencapaian tersebut.

Menurut penuturan Ibu Iyon bahwa pemahaman tentang etika bisnis yang beliau ketahui dengan memulai dagangannya memulai dengan bacaan basmalah, sedangkan untuk waktu shoat wajib beliau telah berada dirumahnya sebelum adzan dhuhur, hal itu menandakan bahwa Ibu Iyon dapat beribadah dengan khusuk dirumahanya. Hal yang menjadi tujuan berbisnisnya adalah untuk menghidupi dan memenuhi pendidikan anaknya dimana mana anak merupakan titipan dari Allah untuk kita penuhi kebutuhannya, baik dari sandang, pangan, papan dan lain sebagainya.

Sedangkan responden Ibu Uswatun kurangnya memahami terkait menyeimbangkan kepentingan dunia dan akhirat akan tetapi kedua responden tersebut tidak pernah berlaku curang pada pembelinya, hal itu menunjukkan bahwa mereka telah menerapakan sebagian dari ketentuan dalam etika bisnis. Malah kedua responden tersebut pernah merasa dirugikan oleh pembeli yang tidak jujur. Ibu Uswatun Hasanah pernah mengalami dimana seorang pembeli yang membawa barangnya dan tidak membayarnya sama sekali sampai jangka waktu yang sangat lama. Hal ini tentu sangat merugikan beliau apalagi yang melakukan kecurangan seperti itu lebih dari satu orang.

Sedangkan menurut penuturan yang diungkapkan Bapak Abdullah beliau memang telah memahami tentang etika bisnis Islam serta beberapa aturan yang berkaitan dengannya, hal tersebut 
dikarenakan beliau memiliki pendidikan yang lebih tinggi dari pada responden lainnya. Bentuk yang menyatakan usaha yang beliau jalani berorientasi kepada Allah ialah setiap beliau akan memulai membuka dagangannya dengan membaca basamalah sama dengan yang dilakukan responden lainnya.

2. Nilai-nilai Kebaikan (ibsan)

Sebagai pedagang muslim sudah sepatutnya bukan hanya berfikir keuntungan pribadi melainkan juga harus berfikir untuk lemaslahatan masyarakat. Karena laba yang sangat tinggi akan merugikan masyarakat dan hal tersebut merupakan salah satu kezhaliman dalam berniaga. Menimbun kebutuhan masyarakat dan berbuat tidak baik pada pembeli tidak dilakukan oleh responden dalam kegiatan binisnya. Karena perlakuan tidak baik akan sangat berpengaruh pada usahanya. Tidak sepatutnya seorang penjual melakukan kepuasannya sendiri tanpa memikirkan kepentingan orang lain, khusunya kaum muslim.

Menimbun barang dagangan termasuk kebutuhan pokok dilarang keras dalam Islam, karena hal tersebut akan berdampak menimbulkan berbagai keresahan masyarakat seperti harga pasar melonjak naik, barang-barang tersebut sulit didapat, keseimbangan permintaan dan penawaran terganggu, dan munculnya para spekulan yang memanfaatkan kesempatan yang memanfaatkan keadaan diatas kesengsaraan masyarakat.

Prinsip kebaikan yang diterpakan Ibu Hedar adalah menerima kembali barang yang dikembalikan pembeli karena cacat yang diketahui setelah sampai dirumah. Ibu hedar akan menggantinya sesuai dengan harga yang telah disepakatakan. Sedangakan yang dilakukan oleh responden lain yaitu Ibu Uswatun Hasanah dia memberikan kebaikan dengan boleh mengkredit barang yang dijualnya. Bentuk keperdulian terhadap sesama seharusnya memang diterapkan oleh pedagang muslim karena memberikan tenggang waktu bagi seorang yang tidak mamapu adalah sesuatu hal yang mulia.

Akan tetapi dalam pelayanan Ibu Hedar pernah tidak bersikap baik kepada pembelinya hal tersebut disebabkan karena beliau memikirkan masalah lain diluar perdagangan sehingga berpengaruh kepada aktivitas jual belinya. Ibu Hedar hati-hati tidak memberi waktu tenggang kepada pembeli yang tidak dikenalnya, karena beliau 
berpengalaman ada pembeli yang tidak menepati janjinya untuk membayar hutang sesuai dengan kesepakatan. Pengalaman tersebut membuat beliau memilih orang yang ingin berhutang.

Menurut peneliti seharusnya pedagang harus melayani dengan baik dan bersikap ramah tanpa mencampur baurkan urusan pribadi dengan aktivitas bisnisnya. Sikap yang baik akan memebuat pelanggan tertarik meskipun hanya dengan meliat-liat bahkan membeli barang yang ditawarkan. Sebailiknya sikap dan perlakuan kasar akan membuat calon pembeli maupun pembeli enggan untuk sekedar melihat barang jualannya, mereka akan melarikan diri dan tidak akan kembali lagi.

3. Keadilan (keseimbangan)

Prinsip keseimbangan menggambarkan keadaan kehidupan pribadi yang bersifat horizontal. Hal ini disebabkan karena dalam berniaga kita lebih banyak berinteraksi dengan sesama. Prinsip keadilan sangat menentukan perilaku kebijakan seseorng. Dalam menangani seluruh masalah kehidupan, Islam menekankan sisi moralitas, karena itu hukumhukum yang ditetapkan Allah, termasuk dalam ekonomi/bisnis, selalu dikaitkan-Nya dengan moral yang melahirkan hubungan tmbal balik yang harmonis. Peraturan, syarat yang mengikat, serta sanksi yang menanti merupakan tiga hal yang selalu berkaitan dengan bisnis, dan diatas tiga hal tersebut ada etika. ${ }^{1}$

Prinsip keseimbangan yang dilakukan oleh pedagang sayur pasar tradisional manggisan tanggul berupa tidak mengurangi timbangan barang yang akan dijual pada pembeli dan tidak menyembnyikan cacat yang ada pada dagangannya. Para responden sangat memahami tentang kebarokahan dalam laba yang diperolehnya. Hal itu menjadi harapan seluruh responden.

4. Kejujuran

Salah satu konsekuensi dari kejujuran adalah pemenuhan janji dan syarat-syarat perjanjian. Dua pihak yang bertransaksi pada dasarnya saling percaya antara kebenaran mitranya dalam segala hal yang berkaitan dengan bisnis mereka. Jika janji atau syarat perjanjian diabaikan.

Prinsip kejujuran yang dilakukan oleh Bapak Abdullah, beliau menimbun barang dagangannya kecuali hanya garam, itupun bukan

${ }^{1}$ Quraish Shihab, Bisnis Sukses Dunia Akhirat,(Cet. II; Tangerang: Lentera Hati, 2013), h. 23

216 | FENOMENA, Vol.18 No. 2 Oktober 2019 
berniat untuk menaikkan harga, lagi pula garam bukan termasuk barang atau kebutuhan pokok. Sama halnya dengan yang dilakukan Bapak Niman mengkulak wortel dan kentang bukan berniat untuk menimbun lalu menaikkan harga akan tetapi mengakulak dengan jumlah banyak dengan tujuan untuk menghemat biaya transportnya tidak ada kaitannya dengan penimbunan barang yang dilarnga dalam Islam.

Sikap tidak baik dalam jual beli seperti Kebohongan, penipuan, dan saling mendholimi sangat dilarang dalam aturan Islam. Islam sangat membenci berlaku curang dalam timbangan, sukatan dan takaran. Islam menganjurkan melakukan takaran atau timbangan terhadap barang yang diperjual belikan dengan jujur dan benar Jangan melebihkan timbangan untuk diri sendiri.

Kejujuran merupakan prinsip yang sangat penting dalam aktivitas bisnis, seseorang yang tidak jujur dalam melakukan bisnis bukan hanya berakibat kecaman oleh Islam, akan tetapi berdampak pada kepuasan pembeli yang berakibat pada kelancaran usaha yang dilakukan. Oleh karena itu seorang pedagang muslim perlu memperhatikan sikap jujur yang ditekankan dalam etika bisnis Islam.

\section{PEMBAHASAN}

Bisnis merupakan salah satu kegiatan ekonomi yang dilakukan dua pihak atau lebih untuk menghasilkan suatu keuntungan bagi pelakunya. Seperti para pedagang sayur di pasar Manggisan Tanggul. Pasar didirikan disamping menjadi tempat interaksi antar sesama melalui jalur niaga, juga agar dapat memenuhi kebutuhan sehari-hari. Al-Ghazali adalah seorang ilmuan muslim yang menyumbangkan pikirannya salah satunya tentang etika yang harus ada dalam pelaksanaan bisnis. Dalam melakukan aktivitas bisnis, Al-Ghazali menekankan untuk senantiasa berpedoman terhadap etika bisnis Islam, prinsip yang dikenkan Al-Ghazali anatara lain yaitu:

a. Ketuhanan

Dimana dalam menjalankan bisnis kita dilarang untuk menjalankannya dengan melupakan kepentingan akhirat. Bersikap ramah kepada pembeli dengan berbuat sesuatu yang bermanfaat bagi kepentingan orang lain. Seorang pedagang muslim harus memiliki niat yang baik dalam usahanya seperti menyelamatkan dari meminta-minta kepada orang lain yang sangat dibenci oleh Allah. Membiasakan diri selalu berdzikir kepada Allah 
Swt dalam keadaan apapun, di pasar, toko, sedang berjual beli dan seluruh aktivitas positif lainya. Berdzikir kepada Allah Swt di pasar, tempat dimana kebanyakan orang justru lupa, adalah lebih afdhal atau lebih utama bagi yang melakukannya. ${ }^{1}$ Allah menjadikan alam dưnia ini dan seluruh isinya sebagai tempat manusia berusaha untuk mencari nafkah, seklaigus ladang beramal. Sedangkan alam akhirat merupakan tempat diberikannya balasan atas semua usaha manusia selama didunia. Bisa pahala, bisa juga siksa bergantung usaha manusia selama menjalani kehidupan di alam dunia. ${ }^{1}$

6

b. Kejujuran

Seorang yang berniaga harus berlaku jujur terhadap barang yang akan dijual seperti jujur terhadap kualitas barang yang akan di jual kepada pemebeli. Seorang pedagang muslim yang tidak jujur dalam berniagaadalah termasuk orang-orang yang zalim terhadap saudaranya hal tersebut sangat dikecam oleh Islam. Pandangan Al-Ghazali tentang sosialekonominya didasarkan pada konsep yang disebut dengan fungsi kemaslahatan sosial (Maslahab). Menurut Mustafa Anas Zarqa, Al-Ghazali merupakan cendikiawan muslim pertama yang merumuskan konsep kesejahteraan (maslahah) sosial. Menurutnya maslahah adalah memelihara tujuan syari'ah yang terletak pada perlindungan agama (din), jiwa (nafs), akal (aql), keturunan (nasab), dan harta (mal). Tema yang menjadi pangkal tolak ukur dari seluruh karyanya adalah adalah konsep maslahat atau kesejahteraan sosial, yakni konsep yang mencakup seluruh aktivitas manusia dan membuat kaitan yang erat antar individu dengan masyarakat. ${ }^{1}$

c. Keadilan

Prinsip kadilan yang diajarkan Al-Ghazali dengan tidak menimbun barang pokok yang menjadi kebutuhan masyarakat tidak dilakukan oleh para responden karena barang yang mereka jual tergolong barang yang tidak dapat bertahan dalam waktu lama karena hal tersebut dapat berdampak pada melonjaknya harga pasar dan kesengsaraan masyarakat dengan sulitnya mencari kebutuhan pokok. Kebaikan, dalam hal ini yang dapat dilakukan berupa tidak terlau banyak mengambil keuntungan, menaikkan harga setinggi-tingginya merupakan kezhaliman.

${ }^{1}$ Al-Ghazali, Ihya' Ulumiddin, h. 126.

1 Ibid. h 91 6

1 Fahadil Amin Al-Hasan, Etikä Bisnis Al-Ghazali, h. 9. 


\section{Diny Duratul Ummah, Ainul Churria Almalachim}

Mengambil keuntungan sedikit merupakan salah satu perbuatan baik dalam berniaga. Hal lainnya adalah dengan bersikap ramah serta memeberi tenggang waktu bagi pembeli yang tidak dapat membayar secara langsung. Prinsip keseimbangan menggambarkan keadaan kehidupan pribadi yang bersifat horizontal. Hal ini disebabkan karena dalam berniaga kita lebih banyak berinteraksi dengan sesama. Prinsip keadilan sangat menentukan perilaku kebijakan seseorng. Dalam menangani seluruh masalah kehidupan, Islam menekankan sisi moralitas, karena itu hukum-hukum yang ditetapkan Allah, termasuk dalam ekonomi/bisnis, selalu dikaitkan-Nya dengan moral yang melahirkan hubungan tmbal balik yang harmonis. Peraturan, syarat yang mengikat, serta sanksi yang menanti merupakan tiga hal yang selalu berkaitan dengan bisnis, dan diatas tiga hal tersebut ada etika. ${ }^{1}$

Pada dasarnya, berjual-beli merupakan bentuk usaha untuk memperoleh laba, dan laba tidak akan didapat kecuali dengan menaikkan harga barang yang akan dijual kepada pembeli. Sedangakn menaikkan harga setinggi-tingginya tidak dituntunkan, karena kecenderungannya yang mengarah pada tindak kezhaliman dan menzhalimi pihak lain. Mengambil keuntungan yang sedikit merupakan salah satu perbuatan baik atau ibsan dalam berniaga. Akan tetapi, apabila pembeli dengan menambahkan lebih dari harga yang ditetapkan (harga jual), maka hendaknya menerima (dihalalkan). ${ }^{1}$

d. Nilai-nilai kebaikan

Dalam melakukan muamalah dengan manusia, seseorang harus memili kinilai-nilai kebaikan yang memang harus di terapkan dalam menjalankan bisnisnya. Dari hasil wawancara dengan 5 responden semuanya menerapkan etika bisnis. Dari lima orang tersebut tidak melakukan hal yang tidak baik yang biasanya ada dalam perdagangan, seperti mengurangi timbangan, sangat tinggi mengambil laba, tidak jujur pada cacat barang, serta bersikap kasar pada pembeli. Harga yang ditawarkan 5 responden relatife sama dengan pedagang lainnya.

Sebagai pedagang muslim sudah sepatutnya bukan hanya berfikir keuntungan pribadi melainkan juga harus berfikir untuk lemaslahatan masyarakat. Karena laba yang sangat tinggi akan merugikan masyarakat

1 Quraish Shihab, Bisnis Sukses, h. 23.

1 Al-Ghazali, Ihya' Ulumiddin, h. 91

FENOMENA, Vol.18 No. 2Oktober 2019 | 219 
dan hal tersebut merupakan salah satu kezhaliman dalam berniaga. Menimbun kebutuhan masyarakat dan berbuat tidak baik pada pembeli tidak dilakukan oleh responden dalam kegiatan binisnya. Karena perlakuan tidak baik akan sangat berpengaruh pada usahanya. Tidak sepatutnya seorang penjual melakukan kepuasannya sendiri tanpa memikirkan kepentingan orang lain, khusunya kaum muslim.

Menimbun barang dagangan termasuk kebutuhan pokok dilarang keras dalam Islam, karena hal tersebut akan berdampak menimbulkan berbagai kereshan masyarakat seperti: harga pasar melonjak naik, barangbarang tersebut sulit didapat, keseimbangan permintaan dan penawaran terganggu, dan munculnya para spekulan yang memanfaatkan kesempatan yang memanfaatkan keadaan diatas kesengsaraan masyarakat.

Sayyida Ali ibn Abi Thalib Ibn Umar ra. Pernah mengatakan, "siapa saja yang menimbun makanan yang dIbutuhkan oleh banyak orang, meskipun hanya sehari, agar dapat dijual dengan harga yang lebih mahal dimasa mendatang, maka akan tertutuplah qalbunyadari cahaya Allah.

Prinsip kebaikan yang diterpakan Ibu Hedar adalah menerima kembali barang yang dikembalikan pembeli karena cacat yang diketahui setelah sampai dirumah. Ibu hedar akan menggantinya sesuai dengan harga yang telah disepakatakan. Sedangakan yang dilakukan oleh responden lain yaitu Ibu Uswatun Hasanah dia memberikan kebaikan dengan boleh mengkredit barang yang dijualnya. Bentuk keperdulian terhadap sesama seharusnya memang diterapkan oleh pedagang muslim karena memberikan tenggang waktu bagi seorang yang tidak mamapu adalah sesuatu hal yang mulia.

Para responden juga sangat mempelakukan para pembelinya dengan baik. Perlakuan baik adalah cerminan dari seorang pedagang muslim yang baik. Keramahan yang diterapkan oleh para pedagang akan berbuah kenyamanan dari para pembelinya sehingga usaha yang dilakukan lancar. Dari pernyataan yang diungkapkan beberapa responden dapat diketahui bahwa perilaku etika bisnis yang dilakukan oleh para responden telah sesuai dengan beberapa prinsip etika bisnis Al-Ghazali, hanya saja dalam penerapannya mereka tidak mengerti bahwa apa yang mereka lakukan merupakan prinsip dari etika bisnis Islam. Meskipun ada beberapa pihak yang tidak sepenuhnya mengerti tentang teori etika bisnis 
Islam, dimana perlakuan baik mereka hanya mengacu pada budaya yang selama ini melekat dimasyarakat.

\section{KESIMPULAN}

Perilaku etika bisnis yang dilakukan para responden yang diteliti adalah dari aspek ketauhidan, kejujuran, keadilan dan kebaikan (ihsan). Dari keempat aspek yang diteliti dapat disimpulkan bahwa para pedagang sudah memiliki perilaku yang baik, akan tetapi masih ada satu pedagang yang tidak bersikap ramah pada pembelinya, menurut pedagang tersebut hal itu terjadi ketika memiliki masalah pribadi sehingga berakibat juga pada rasa emosinya pada pembeli. Meskipun sikap tersebut tidak selalu dilakukannya akan tetapi seharusnya tidak dilakukan oleh seorang pedagang muslim bagaimanapun kondisinya harus tetap bersikap ramah pada pembeli.

Oleh sebab itu sudah menjadi tugas pemerintah unit pasar sebagai pemegang kendali dari segala kegiatan pasar Manggisan Tanggul. Pertama, memberi edukasi kepada para pedagang tentang bagaimana bertransaksi sesuai etika bisnis Islam. Kedua, Perlu diadakan sosialisasi atau penyuluhan bagi para pedagang untuk meningkatkan wawasan dan pengetahuan pedagang agar mengerti manfaat dan tujuan dari etika bisnis dalam transaksi jual beli. Ketiga, Adanya standarisasi timbangan untuk timbangan yang akan digunakan oleh pedagang, sehingga ada kesamaan timbangan antara pedagang satu dengan yang lainnya. Keempat, Kesadaran dan peran masyarakat dalam hal ini para pembeli juga seharusnya memahami prinsip etika bisnis yang ditekankan dalam Islam sehingga kedepannya tidak ada hambatan yang menyebabkan kerugian, kekecewaan, serta ketidak adilan yang bisa saja terjadi pada pedagang maupun pembeli. Sehingga transaksi yang dilakukan menjadi transaksi yang menguntungkan dunia dan akhirat.

\section{DAFTAR PUSTAKA}

Al-Ghazali, (2016). Ibya' Ulumiddin, terj. Ibnu Ibrahim Ba’adillah, Cet. II; Jakarta: Gramedia.

Al-Hasan, Fahadil Amin. (2014). Etika Bisnis Al-Ghazali. Jurnal E-Sya. Vol. 1 No. 1. Bandung.

Ali, Zainuddin. (2008). Metode Penelitian Hukum, (Cet. 2. Jakarta: Sinar Grafika, 2010. 
Chamid, Nur. (2010). Jejak Langkah sejarah Pemikiran Ekonomi Islam, (Cet. 1; Yogyakarta: Pustaka Pelajar.

Dendy, sugono, Kamus Besar Bahasa Indonesia, Cet. IV; Gramedia Pustaka Utama.

Departemen Agama RI, Al-Qur'an dan terjemahnya (Tangerang: Kalim)

Kusnia, Siti Mina. (2015) Perilaku Pedagang di Pasar Tradisional Ngaliyan Semarang Dalam Perspektif Etika Bisnis Islam, Skripsi. Semarang: UIN Walisongo.

Mardiyah, Ema. Asep Suryanto. (2010). Analisis Penerapan Etika BisnisSyari'ah di Pasar Tradisional Singaparna Kab. Tasikmalaya, Skerpsi (Fakultas Ekonomi Universitas Tasikmalaya)

Marzuki, Peter Mahmud. (2005). Penelitian Hukum, Jakarta: Kencana.

Norvadewi, Bisnis dalam Perspektif Islam (Telaab Konsep, Prinsip dan Landasan Normatif). Jurnal AL-TIJARY. 2015. Vol. 01. No.01.

Rahmadani, Dyan Arurum. (2017). Perilaku pedagang di Pasar Tradisional Petepapus Makassar dalam Perspektif Etika Bisnis Islam, Skripsi (Makassar: Fakultas Ekonomi dan Bisnis Islam UIN Alauddin Makassar)

Rianto, Misdi. (2010). Pemikiran Al-Ghazali tentang Mekanisme Pasar dalam Islam, Skripsi (Riau: UIN Sultan Syarif Kasim)

Safitri, Ligaya. (2015). Etika Bisnis Mahasiswa (Studi Kasus pada Mahasiswa Prodi Ekonomi Islam Angkatan 2011 Fakultas Ekonomi dan Bisnis Islam UIN Wali Songo Semarang), skripsi, (Semarang :UIN Wali Songo)

Shihab, M. Quraish. (2013). Bisnis Sukses Dunia Akhirat. Cet. II. Tangerang; Lentera Hati.

Sugiyono. (2012). Metode Penelitian Kuantitatif, Kualitatif Dan R\&D Bandung: Alphabet. 